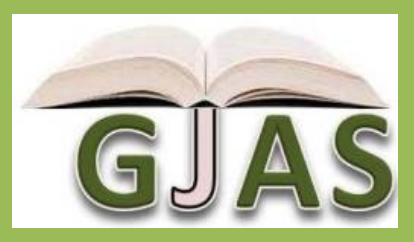

\title{
Potency of Some Plant Extracts and Pesticides on Bacterial Leaf Blight Diseases of Cocoyam (Colocasia Esculenta) in Umudike, South Eastern Nigeria
}

\section{Emma Opara*1, Theresa C. Njoku² and Chikodi Isaiah ${ }^{3}$ \\ ${ }^{1 *},{ }^{3}$ Department of Plant Health Management, Michael Okpara University of Agriculture, Umudike. \\ ${ }^{2}$ Department of Crop Science, Imo State University, Owerri.}

Article No.: 022013484

DOI: 10.15580/GJAS.2013.5.022013484

Submitted: 20/02/2013

Accepted: 22/05/2013

Published: 29/05/2013

${ }^{*}$ Corresponding Author

Emma Opara

E-mail: euopara22@yahoo.com

Phone: 08035761578

\section{Keywords:}

Colocasia esculenta, bacterial leaf

blight, plant extracts,

Xanthomonas campestris pv.

Campestris
A pot trial was conducted in 2010 and 2011 cropping seasons at the screen house of Michael Okpara University of Agriculture, Umudike to determine the potency of some plant extracts and pesticides for the control of bacterial leaf blight of cocoyam (Colocasia esculenta L.) Scholt. The materials employed include: lemon grass (Cymbopogon citrates), Black pepper seed (Piper guineense), orange peel (Citrus sinesis), streptomycin sulphate (antibiotic), copper oxychloride (fungicide) and sterile water (control). The experiment was laid in complete randomized design (CRD) and replicated six times. The plant materials used were first made into aqueous extracts using cold water extraction and diluted to $10 \%$ concentration. Application on leaves was by use of a hand sprayer for two weekly intervals. Data were collected on disease severity and incidence including growth parameters and on yield of corms. The results obtained showed that all the plant extracts were able to reduce disease and increase yield better than the untreated control. 


\section{INTRODUCTION}

Cocoyam Colocasia esculenta (L.) Scholt constitutes one of the basic food crops of major economic importance in the south eastern Nigeria. It ranks the third after cassava and yam, in terms of total production, land area under crop and consumption (Chukwu and Nwosu, 2008). There are two main edible types of cocoyam in Nigeria viz: Colocasia exculenta (L.) Scholt, otherwise known as 'taro' and Xanthosoma saggittifoleium also known as 'tannia' (Arene and Ene, 1987). The former is by far more popular than the later. Taro requires heavy fertile upland soil and plentiful rainfall for good yield. It does well also in a fertile low land environment (Agboola, 1987; Anikwe et al., 2007) and commonly grown in South Eastern zone of Nigeria. On the other hand, tannia (Xanthosoma saggittifollium) is well cultivated in the South Western zone of Nigeria (Ikwelle, 1999).

Currently, Colocasia exculenta (taro) is seriously threatened to extinction in south eastern Nigeria as a result of its high susceptibility to bacterial leaf blight disease. Therefore this study was undertaken to isolate and identify the causal organism and determine the potency of some selected local plant extracts in the control of bacterial leaf blight of Colocasia esculenta.

\section{MATERIALS AND METHODS}

The study was carried out for two years during the 2010 and 2011 cropping seasons under pot trials. Top soil was collected from the Eastern farm site of the Michael Okpara University of Agric, Umudike. Soil analysis and characterization was conducted to determine the macro and micro elements and other constituents of the soil. The soil was then poured into a cut drum, moistened and the temperature raised until it reached a temperature of $80^{\circ} \mathrm{C}$ for 20 minutes for proper sterilization, and then allowed to cool down before mixing with poultry droppings and fine soil (to improve its porosity) in the ratio of 3: 2: 1 of top soil, fine sand and poultry droppings respectively (the poultry dropping was allowed to decompose for two weeks before use) and later the sterilized soil mixture dispensed into plastic pots of $15 \mathrm{~cm}$ in diameter (three quarter filled).

The experiment was arranged in a completely randomized design (CRD) consisting of six treatments and six replications. The plant materials used as extracts were lemon grass (Cymbopogon citrates) black pepper seed (Piper guineense), orange peel (Citrus sinensis) and two synthetic pesticides namely streptomycin sulphate and copper oxychloride. Cocoyam corms were planted into experimental pots at the rate of one seedling per pot.

\section{PREPARATION OF PLANT EXTRACTS}

The plant materials collected were washed and air dried and $50 \mathrm{~g}$ weighed out before grinding them into powder for use in this study. The powdered material was suspended in $100 \mathrm{ml}$ of sterile water and later diluted to $20 \%$ concentration, allowed to stand in water for 24 hours after which the suspension was filtered using cheese cloth and the filtrate obtained used as cold water aqueous extracts diluted (Stoll, 2000: Amadioha, 2003). Also two synthetic pesticides, which included streptomycin sulphate (antibiotic) and copper oxychloride (fungicide) were dissolved in cold sterile water to obtain, $1 \%$ and $10 \%$ respectively which served as positive checks (Whitehead, 1999), also sterile water was served as control experiment.

\section{PREPARATION OF BACTERIAL INOCULUM}

Infected leaf samples were collected from the university farms and brought into the laboratory, thoroughly washed with sterile water and were surface sterilized for 10 seconds in $(0.5 \%)$ aqueous solution of sodium hypochlorite, the leaf samples were cut $\left(4 \mathrm{~mm}^{2}\right)$ from the junction of healthy and diseased leaf tissue (Bradbury, 1975). Each sample was placed on a sterile microscopic slide, covered with a drop of sterile water and observed under a dissecting microscope (x 25). Also the sterilized a small piece of infected portion was placed in a drop of water inside a Petri-dish, teased apart and allowed to stay for 30mins to enable the multiplication of the bacterium before inoculating unto the culture media.

\section{PREPARATION OF MEDIUM AND INOCULATION OF THE PATHOGEN}

The medium used in bacteria culture was nutrient agar (NA) which was prepared by weighing out $7 \mathrm{~g}$ of readymade nutrient agar powder into a conical flask and dissolving in $250 \mathrm{ml}$ of sterile water (Fahy and Hayward, 1983). The mixture was thoroughly shaken and then autoclaved at $120^{\circ} \mathrm{C}$ for $151 \mathrm{~b}$ for 30 minutes. This was followed by pouring $15 \mathrm{ml}$ of the medium into $9 \mathrm{~cm}$ diameter Petri dishes after it has cooled down to $45^{\circ} \mathrm{C}$. The nutrient agar was kept in an incubator at 28 $30^{\circ} \mathrm{C}$ for 8 hours to enhance drying of the surface agar in the Petri dishes before use.

Prior to inoculation of bacterial suspension into the medium, the inoculation chamber was thoroughly mopped with $70 \%$ absolute alcohol using sterile cotton wool to prevent contamination. The bacterial suspension was streaked onto the nutrient agar (NA) in Petri dishes using a flamed wire loop after which the culture was placed in an incubator at $30^{\circ} \mathrm{C}$ for 48 hours. The culture colonies obtained after $48 \mathrm{hrs}$ was sub-cultured severally to obtain pure bacterial colonies. A standard bacterial inoculum concentration was obtained by serial dilution plating by addition of $5 \mathrm{ml}$ of sterile water into the culture colonies and then using wire loop to mix the colonies with water into suspension which was adjusted to the concentration of $10^{8} \mathrm{cfu} / \mathrm{ml}$ using haemocytometer to obtain a 
concentration of $10^{8} \mathrm{cfu} / \mathrm{ml}$ (colony forming unit per meal).

\section{PATHOGENICITY TEST AND INOCULATION OF COCOYAM SEEDLINGS}

The 36 pots each containing one cocoyam plant per pot were arranged in completely randomized design (CRD) with six replicates. The cocoyam seedlings were pre- inoculated using the bacterial inoculum of a concentration of $10^{8} \mathrm{cful} / \mathrm{ml}$ before the application of plant extracts. The seedlings were inoculated by spraying the bacterial inoculum on the leaves using hand atomizer in the evening (6-6:30pm). The younger leaves and emerging shoots were also sprayed until there was a run-off. The inoculated seedlings were later covered with transparent polythene bags to create a high humid condition and allowed for 48 hours at $25-27^{\circ} \mathrm{C}$ for the bacterial pathogen to incubate (Jones et al., 2000).

\section{APPLICATION OF AQUEOUS PLANT EXTRACTS}

The three aqueous plant extracts used were obtained from: lemon grass (Cymbopogon citrates) black pepper seed (Piper guineense), orange peel (Citrus sinensis). To compare their performance with standard synthetic pesticides an antibiotic (streptomycin sulphate) and a fungicide (copper oxychloride) were used as positive checks while sterile water served as untreated control. The aqueous extracts and pesticides were applied on the cocoyam leaves in the same way as the bacterial inoculation, but seven days after bacterial inoculation using an atomizer (Opara and Wokocha, 2008).

\section{DISEASE SEVERITY INDEX AND \% DISEASE INCIDENCE}

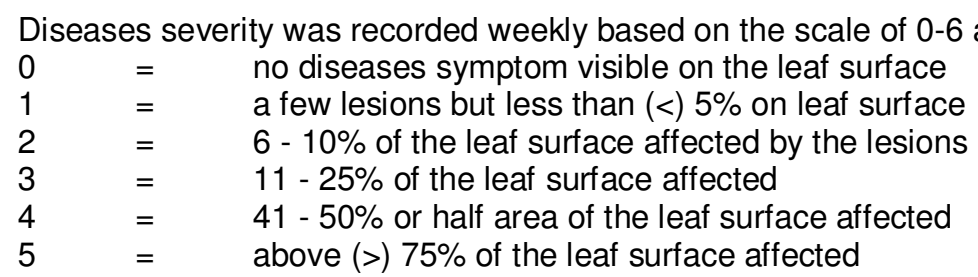

\section{DISEASE INCIDENCE}

The disease incidence was determined as follows:

Percentage $(\%)$ disease incidence $=\quad \frac{\text { Number of leaves affected }}{\text { Total number of leaves sampled }} \quad X \quad \frac{100}{1}$

Data on growth and yield parameters were collected fortnightly, starting from one week after treatment (extract) application or four weeks after planting based on: Plant height $(\mathrm{cm})$, Number of leaves, Leaf area index $(\mathrm{cm})$, and the number of corms and weight of corms $(\mathrm{g})$.

The scores based on first 5 leaves from the youngest open foliage were used to assess the disease severity while disease incidence was obtained by the percentage of affected number of leaves per plant and per replication.

\section{Data Analysis}

The data collected from the experiment were statistically analyzed using analysis of variance (ANOVA) and Fishers-LSD at $P<0.05$ to separate the means according to the procedures outlined by Steel and Torrie (1980).

\section{RESULTS}

\section{Soil Analysis and Characterization}

The result of soil sample analyzed is summarized in Table1 below. 
Table 1: Properties of the soil sample collected at 0-30 cm depth

\begin{tabular}{ll}
\hline Soil & Characteristics \\
\hline Texture & Loamy sand \\
Sand $(\%)$ & 61.33 \\
Silt $(\%)$ & 6.00 \\
Clay $(\%)$ & 32.66 \\
Organic carbon $(\%)$ & 1.35 \\
organic matter $(\mathrm{mg} / \mathrm{kg})$ & 15.0 \\
Nitrogen $(\%)$ & 0.11 \\
$\mathrm{Ca}\left(\mathrm{cmo} / \mathrm{kg}^{-1}\right)$ & 2.93 \\
$\mathrm{Ma}\left(\mathrm{cmo} / \mathrm{kg}^{-1}\right)$ & 1.26 \\
$\mathrm{~K}\left(\mathrm{cmo} / \mathrm{kg}^{-1}\right)$ & 0.16 \\
$\mathrm{Na}\left(\mathrm{cmo} / \mathrm{kg}^{-1}\right)$ & 0.23 \\
$\mathrm{P}\left(\mathrm{cmo} / \mathrm{kg}^{-1}\right)$ & 5.20 \\
Ex. acidity $\left(\mathrm{cmo} / \mathrm{kg}^{-1}\right)$ & 1.10 \\
ECEC $\left(\mathrm{cmo} / \mathrm{kg}^{-1}\right)$ & 5.69 \\
$\mathrm{pH}(\mathrm{H} 20)$ & 4.70 \\
\hline
\end{tabular}

\section{Pathogenicity Test}

Results of pathogenicity test conducted showed that bacterium pathogen from cocoyam induced symptoms in the leaves, which appeared within 3-4 days after inoculation and by 7-8 days, lesions increased to $1 \mathrm{~cm}$ in diameter, coalesced and prominent chlorotic halos developed around the lesions similar to those observed in the infected field. The control experiment however showed no such symptoms or lesions at all. Within another one week, spots and lesions on the upper surface turned gray brown with the chlorotic halos becoming enlarged, in the crops inoculated with the pathogen. These symptoms were indistinguishable from those reported for Xanthomonas pv. disffenabachiae in Florida (Ken et al.,1985).

\section{Biochemical and Cultural Analysis of the Pathogen}

The result of some biochemical and cultural tests conducted on the pathogen are shown in Tables 2 and 3

below.

Table 2: Cultural characteristics of the pathogen

\begin{tabular}{ll}
\hline Tests & Characteristics \\
\hline Colour and texture of colonies & Muciod, yellow, creamy and pale yellow \\
Gram staining Test & Gram negative rods \\
Microscopic Examination & Motile, no spores or capsules \\
Colony Characteristic and shape & Mucoid and convex \\
& \\
\hline
\end{tabular}

Table 3: Biochemical characteristics

\begin{tabular}{ll}
\hline Tests & Results \\
\hline Gram reaction & - \\
Starch hydrolysis & + \\
Catalase activity & - \\
Gelatin hydrolysis & + \\
Oxidase activity & - \\
Acid Production from: & + \\
Glucose & + \\
Mannose & + \\
Arabinose & $*$ \\
\hline
\end{tabular}

Following the results of physiological and biochemical analysis including pathogencity tests conducted, it was concluded that the bacterium isolated from leaf spot of cocoyam in Umudike, South Eastern Nigeria for
Xanthomonas pv. disffenabachiae was similar to the report made in Florida and the strain identified as $X$. disffenabachiae (Ken et al.,1985). 
Table 4: Effect of plant extracts on disease severity, growth parameters and yield parameters on Colocasia in the pot trial during the $\mathbf{2 0 1 0}$ cropping season

\begin{tabular}{|c|c|c|c|c|c|c|}
\hline Treatment & $\begin{array}{l}\text { Disease } \\
\text { severity }\end{array}$ & $\begin{array}{l}\text { Leaf Area } \\
\text { (cm) }\end{array}$ & $\begin{array}{l}\text { No. of } \\
\text { Leaf }\end{array}$ & $\begin{array}{l}\text { Plant ht. } \\
\text { (cm) }\end{array}$ & $\begin{array}{l}\text { No. of } \\
\text { corm }\end{array}$ & $\begin{array}{l}\text { Wt. of corm } \\
\text { /plant }(\mathrm{kg})\end{array}$ \\
\hline Streptomycin & 1.33 & 4.10 & 4.17 & 30.67 & 3.25 & 2.90 \\
\hline $\begin{array}{l}\text { Copper } \\
\text { oxychloride }\end{array}$ & 1.67 & 3.13 & 3.83 & 30.33 & 3.00 & 2.30 \\
\hline $\begin{array}{l}\text { Cymbopogon } \\
\text { citratus }\end{array}$ & 1.83 & 2.64 & 2.50 & 23.00 & 3.00 & 1.70 \\
\hline $\begin{array}{l}\text { Piper } \\
\text { guneense }\end{array}$ & 1.33 & 2.95 & 3.50 & 30.00 & 3.60 & 2.60 \\
\hline $\begin{array}{l}\text { Citrus sinensis } \\
\text { peel }\end{array}$ & 1.17 & 4.83 & 5.00 & 31.50 & 3.85 & 2.80 \\
\hline $\begin{array}{l}\text { Sterile water } \\
\text { control }\end{array}$ & 3.00 & 2.14 & 2.00 & 22.17 & 1.00 & 1.30 \\
\hline LSD $(P \leq 0.05)$ & $0.57^{*}$ & NS & $1.81^{*}$ & $6.05^{\star \star}$ & $1.02^{*}$ & $0.80^{*}$ \\
\hline
\end{tabular}

\section{Effect of Plant Extracts on Disease Severity}

The results obtained for the two years (2010 and 2011) on disease severity are summarized in Tables 1 and 2. Plants treated with Citrus sinensis peel (1.17 and 1.00) and Piper guineense (1.33 and 1.00) during the 2010 and 2011 trials proved more effective than the other treatments and were even as good as the standard antibiotic (streptomycin sulphate) in reducing the disease severity and their means differed significantly from that of the sterile water i.e. the control treatment $(p \leq 0.05)$.

\section{Effect of Plant Extracts on Growth Parameters}

For leaf area, there was no significant differences observed in their treatments during the 2010 cropping season, however in the 2011 season plants treated with $C$. sinensis peel gave the highest leaf area (10.65) after the standard antibiotic - streptomycin $(11.13 \mathrm{~cm})$ when compared with sterile water $(7.79 \mathrm{~cm})$.

Regarding the number of leaves, $C$. sinensis peel treated seedlings proved to be the highest mean number per plant (5.0) followed by streptomycin (4.17) while sterile water gave the least (2.0) which differ significantly at $\mathrm{P} \leq 0.05$ for the two years under trials. For plant height, $C$. sinensis peel still gave the best (31.50) compare with sterile water (22.17) at $\mathrm{P} \leq 0.05$.

\section{Effect of Plant Extracts on Crop yield}

From the results obtained during the two cropping seasons, $C$. sinensis peel produced the highest in terms of the number of corms per plant (3.85 and 8.00) followed by streptomycin (3.25 and 8.00$)$ while the least was recorded for sterile water (1.00 and 3.00) which differ significantly from others at $P<0.05$. However, for the weight of corm, streptomycin gave the best $(2.90 \mathrm{~kg})$ in the first year followed by $C$. sinensis peel (2.80kg in 2010 and $2.62 \mathrm{~kg}$ in 2011 ) and $P$. guineense (2.60kg for 2010 and $2.22 \mathrm{~kg}$ in 2011), i.e. in the second year $P$. guineense $(2.22 \mathrm{~kg})$ performed as good or even better than the standard antibiotic, streptomycin $(2.08 \mathrm{~kg})$ in the second cropping season (i.e. 2011) next to $C$. sinensis $(2.62 \mathrm{~kg})$ and their means differed significantly from that of control, sterile water $(1.05 \mathrm{~kg})$ at $\mathrm{P} \leq 0.05$. 
Table 5: Effect of plant extracts on disease severity, growth parameters and yield parameters on Colocasia in the pot trial during the 2011 cropping season

\begin{tabular}{|c|c|c|c|c|c|c|}
\hline Treatment & $\begin{array}{l}\text { Disease } \\
\text { severity }\end{array}$ & $\begin{array}{l}\text { Leaf } \\
\text { Area } \\
\text { (cm) }\end{array}$ & $\begin{array}{l}\text { No. of } \\
\text { Leaf }\end{array}$ & $\begin{array}{l}\text { Plant ht. } \\
\text { (cm) }\end{array}$ & $\begin{array}{l}\text { No. of } \\
\text { corm }\end{array}$ & $\begin{array}{l}\text { Wt. of } \\
\text { corm / plant } \\
\text { (kg) }\end{array}$ \\
\hline Streptomycin & 1.00 & 11.13 & 6.50 & 44.50 & 8.00 & 2.08 \\
\hline $\begin{array}{l}\text { Copper } \\
\text { oxychloride }\end{array}$ & 1.17 & 7.84 & 6.17 & 45.67 & 7.00 & 1.70 \\
\hline $\begin{array}{l}\text { Cymbopogon } \\
\text { citratus }\end{array}$ & 1.17 & 7.44 & 6.00 & 40.00 & 7.67 & 1.85 \\
\hline Piper guneense & 1.00 & 10.26 & 7.83 & 44.00 & 7.00 & 2.22 \\
\hline $\begin{array}{l}\text { Citrus sinensis } \\
\text { peel }\end{array}$ & 1.00 & 10.65 & 7.50 & 46.33 & 8.00 & 2.62 \\
\hline $\begin{array}{l}\text { Sterile water } \\
\text { control }\end{array}$ & 3.49 & 7.79 & 3.00 & 30.00 & 3.00 & 1.05 \\
\hline LSD P $\leq 0.05$ & $0.49^{*}$ & $3.27^{*}$ & $2.12^{*}$ & $4.57^{*}$ & $2.06^{* *}$ & $0.36^{* *}$ \\
\hline
\end{tabular}

\section{Effect of Plant Extracts on Disease Incidence}

Data obtained (Fig.1) during the two years trials showed that plant extracts especially $C$. sinensis $(25 \%$ for both years) and $P$. guneense (25 and $28 \%$ for the $1^{\text {st }}$ and $2^{\text {nd }}$ year respectively) had reduced disease incidence similar to those of streptomycin which is a standard disease incidence while the untreated control recorded high disease incidence (65 and $68 \%$ for the $1^{\text {st }}$ and $2^{\text {nd }}$ year respectively) during the periods under investigation

(Fig.

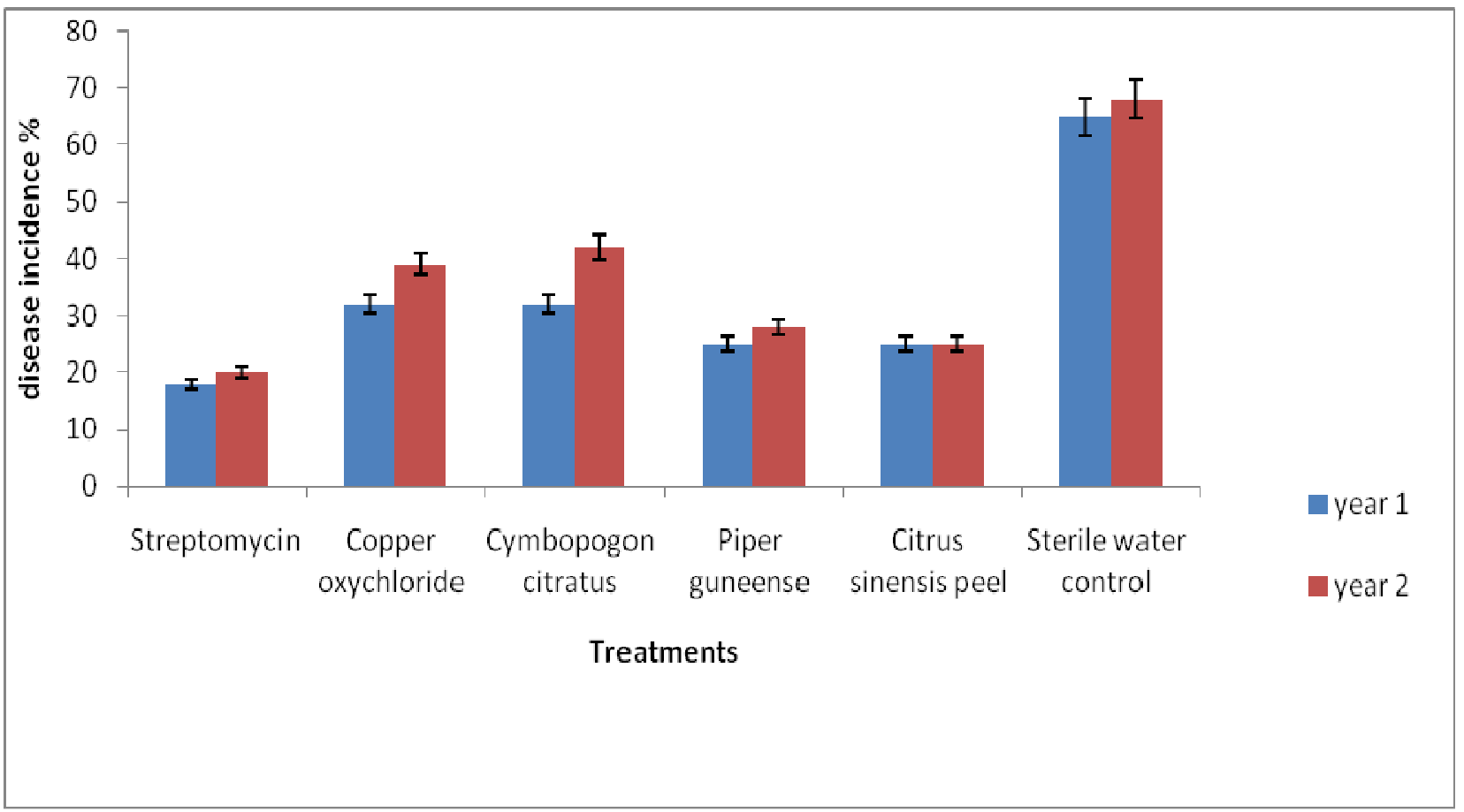

Fig 1: Disease Incidence of cocoyam leaf blight during the 2010 and 2011 pot trials in Umudike. 


\section{DISCUSSION}

This study shows the bactericidal potential and potency of the three plant extracts used namely $C$. sinenesis, $P$. guineese and $C$. citrates in comparison with standard pesticides as far as reducing both disease severity and incidence are concerned and at the same time enhancing growth and yield of cocoyam which is an important staple food crop in south Eastern Nigeria. This work is similar to the those reported by earlier workers (Amadioha, 2003; John and James, 2004; Opara and Wokeocha, 2008) which showed that some indigenous plant species could serve as potential antimicrobial agents against bacterial pathogens. In his work Jacobson (1989) observed that some botanical pesticides were also found among the families of Asteraceae, Lobiatae and Rutaceae. From our observations, all the three plant extracts employed significantly reduced disease severity and incidence of bacterial leaf spot disease of Colocasia when compared with the untreated control (sterile water).

It was also noted that the plant extracts proved to be as effective as standard synthetic pesticides such as antibiotics (streptomycin sulphate) and fungicide (copper oxychloride) and were even in some cases at par with these conventional chemicals usually used in disease reduction, indicating that some natural anti-microbial active ingredients are indeed contained in these plant extracts (Stoll, 2000; John and James, 2004). Opara and Obani (2010) made similar observation in bacterial blight of egg plant. Amadioha (2004) reported that the greater effectiveness of the extracts may be due to inherent chemical constituents or bioactive ingredients of the plant extracts. These active principles in the plant extracts he concluded contain anti-bacterial polyphenolic compounds.

Accordingly the work done by Burnt (1975) showed that synthetic pesticides such as streptomycin and agromycin were found to be systemic in action similar effect could have been employed by the plant extracts on leaf blight disease of cocoyam resulting to disease reduction when compared with the untreated control. It was also noted that for the two years, foliar application of streptomycin sulphate significantly reduced disease severity three times and by $70-80 \%$ in the case disease incidence more than the control experiments. Also, other workers have observed that applying streptomycin sulphate (1000 ppm) a day prior to inoculation was more effective in the controlling bacterial diseases than after inoculation (Ken et al., 1985; Whitehead, 1999). From this study it was also found that, the plant extracts significantly generally improved the amount of yield of corm and cormels further stressing the function of the bactericidal activity of the extracts used.

The specific identity of the causal agent of cocoyam leaf blight has for some time been an issue for discussion. For instance, Berniac (1974) reported that the bacterium isolated from cocoyam leaf blight was identified as Xanthomonas campestris pv. dieffenbachiae while Hayward (1983) reported that the causal agent of bacteria leaf spot of cocoyam was identified as Xanthomonas campestris pv. aracearum. These symptoms were indistinguishable from those reported by Ken et al (1985) for Xanthornonas pv. dieffenbachiae. On the basis of results obtained from the physiological and biochemical tests as well as the pathogencity tests, it was concluded that the bacterium causing leaf blight of cocoyam in Umudike was a strain of $X$. diffenbachiae, similar report was made in Florida and the strain identified as $X$. disffenabachiae (Ken et al.,1985).

Contrary to the results obtained by Berniac (1974), two of the three known $X$. campestris pv. dieffenbachiae isolates from other aroids grown in Florida by Ken et al (1985) induced typical symptoms in cocoyam but was identified as $X$. campestris. pv. diffenbachiae and not $X$. aracearum based on the findings that the cocoyam strains do not produce acid from glycerol. Dye and Lelliot (1974) recognized a distinct pathovar. X. campestris pv. aracearum, for the cocoyam pathogen. However, it was chosen to classify the Florida cocoyam strain as $X$. campestris pv. dieffenbachiae and the historical use of this pathovar designation for the xanthomonads attacking other aroids. The observations also indicates that the pathogen is systemic in cocoyam and $X$. campestris pv. dieffenbachiae has been considered systemic in other hosts. This is the first report of $X$. campestris pv. dieffenbachiae causing cocoyam leaf blight in Nigeria. The significant reduction in disease severity and incidence shows that formulations of plant extracts could have important roles in biologically based strategies for control of diseases caused by $X$. campestris pv. dieffenbachiae.

\section{REFERENCES}

Agboola SD (1987). Cocoyam storage and its full potential for food sufficiency and future economic recovery of Nigeria. Proceedings of $1^{\text {st }}$ National Workshop on cocoyam held at N.R.C.R.I, Umudike Nigeria, pp 42.

Amadioha AC (2003). Evaluation of some plant leaf extracts against Collectorichum lindemuthianum in cowpea. Acta Phytopathol Enthomol, Hungarica. 38:259-265.

Amadioha AC (2004). Control of black rot of potato cause by Rhyzoctonic bataticola using some plant leaf extracts. Arch. phytopathol. Plant prot. 37:111117.

Anikwe MAN, Mbah CN, Ezeaku PI and Onyia VN (2007). Tillage and plastic

mulch effects on soil properties and growth and yield of cocoyam (Colocasia esculenta) on an ultisol in south-eastern Nigeria. 
Arene OB and Ene LSO (1987). Advances in cocoyam research at National Root Crops Research Institute Umudike (1972-1986). Proc. First National Workshop in Cocoyam, NRCRI, UMudike, Nigeria, pp 58-71.

Berniac M (1974). Line Maladie bacterienne de Xanthosoma sagittifolilum (L.) Scholt Annales de phytopathologie. 6 : 197-202.

Bradbury JF (1970). Isolation and preliminary study of bacteria from plants. Review of Plant Pathology. 49: 213-218.

Burnt A (1975). Effect and mode of action of some systemic nematicides. Diss. Agric. Univ. Wageningen. 3: 60-79.

Chukwu GO and Nwosu KI (2008). Cocoyam rebirth. The renaissance of a giant crop. Paper presented at the $17^{\text {th }}$ Annual conference of Nigeria Rural Sociological Association at NRCRI Umudike, $11 \mathrm{pp}$.

Dye DW and Lelliot RA (1974). Genus Xanthomonas (Downson, 1939). In Bergys manual of Determinative Bacteriology, $8^{\text {th }}$ edition, pp 243-249.

Fahy PC and Hayward AC (1983). Media and culture for isolation and diagnostic tests. In: plant bacteria Diseases: a diagnostic Guide. PC Fahy and G Parsley (eds). Academic press New York, pp 15.

Hayward AC (1983). Primary differentiation of General of plant pathogenic bacteria. In: plant bacteria Diseases: a diagnostic Guide. PC Fahy and G Parsley (eds). Academic press New York, pp 15.

Ikwelle MG (1999). Nigeria capacities in root and tuber crops research and production. Proc. Annual review and research planting workshop NRCRI, Umudike, 23-48.
Jacobson MO (1989). Botanical pesticides, past, present and future; insecticides of plant origin, Washington DC, USA: ACS Symposium series 387.

John, H.B. and James C.L. (2004) Effect of formulated plant extracts and oil on population density of Phytophtora nicotiana in soil and control of Phyyopthora blight in Greenhouse. Plant Dis. 88:1116.

Jones JB, Bouzar H, Stall RE, Robert PD, Bowen BW, Sunberry J, Strekler PM and Chin J (2000). Systematic analysis of (Xanthomonas spp.) associated with pepper and tomato lesions. International Journal of Systematic and Evolutionary Microbiology. 50:11-12.

Ken P, Raymond BV and Wilbur D (1985). Bactaria leaf spot of cocoayam (Xanthosoma caracu), incited by Xanthomonas campestris pv. dieffenbachiae, in Florida.

Opara, E.U. and Wokocha, R. C. (2008). Efficacy of some plant extract on the in vitro and in vivo control of Xanthomonas campestris pv. vesicatoria. Agriculture Journal 3(2): 163-170.

Opara, E.U. and Obani, F.T. (2010). Performance of some plant extracts and pesticides in the control of bacterial spot diseases of Solanum. Agriculture Journal 5(2):45-49.

Steel, R.G. and Torrie, J.H. (1980). Principles and Procedure of Statistics: A Biometrical Approach, 2nd ed. McGraw-Hill, New York, 633 pp.

Stoll, G. (2000) Natural Crop Protection in the Tropics and sub tropics. Letting information come to life. $2^{\text {nd }}$ edition, Margraf Veriag, pp: $102-139$.

Whitehead, R. (1999) The Pesticides Guide British crop Protection council CABI Publishing pp. 149-159. 